\section{Evidence for a resident population of cheetah in the Parque Nacional do Limpopo, Mozambique}

\author{
Leah Andresen ${ }^{1 *}$, Kristoffer T. Everatt ${ }^{1}$, \\ Michael J. Somers ${ }^{1,2,3}$ \& Gianetta K. Purchase ${ }^{4}$ \\ ${ }^{1}$ Centre for Wildlife Management, University of Pretoria, \\ Private Bag X20, Hatfield, Pretoria, 0028 South Africa \\ ${ }^{2}$ Mammal Research Institute, University of Pretoria, \\ Private Bag X20, Hatfield, Pretoria, 0028 South Africa \\ ${ }^{3}$ Centre for Invasion Biology, University of Pretoria, \\ Private Bag X20, Hatfield, Pretoria, 0028 South Africa \\ ${ }^{4}$ Zoological Society of London, Wildlife Conservation Society, \\ P.O. Box 2633, Bulawayo, Zimbabwe \\ Recieved 25 September 2012. Accepted 22 October 2012
}

Transboundary protected areas may be important for the conservation of large African carnivores because these species require large tracts of habitat to maintain viable population numbers and gene flow. Cheetah (Acinonyx jubatus Schreber, 1775), is a species that may benefit from transboundary conservation agreements. It occurs at naturally low population densities, makes use of large home ranges, and disperses over long distances, thus requiring large tracts of suitable habitat to maintain viable population numbers. Here we present the first scientific evidence of a breeding population of cheetah in Parque Nacional do Limpopo (PNL), Mozambique. We obtained data from camera-traps deployed during occupancy surveys conducted from 9 September 2011 to 31 August 2012 over a 3400 km $^{2}$ study area located within the central third of PNL. These results highlight the importance of the Greater Limpopo Transfrontier Park (GLTFP) to the overall conservation of cheetah in Africa, and the potential value of transboundary protected areas for the conservation of wide-roaming terrestrial mammals.

Key words: Acinonyx jubatus, Transfrontier Park, transboundary protected area, occupancy surveys.

\section{INTRODUCTION}

Range wide planning for large carnivore conservation benefits from agreements that bridge international boundaries, including transboundary protected areas (Weber \& Rabinowitz 1996). Such areas may be important for the conservation of large carnivores because these species require large tracts of habitat to maintain viable population numbers and gene flow (Woodroffe \& Ginsberg 1998). Furthermore, at a time when many large

\footnotetext{
*To whom correspondence should be addressed
}

E-mail: wildedens@gmail.com carnivores have become locally extirpated, transboundary protected areas can act as reservoirs, permitting species to recolonize portions of their former range (Weber \& Rabinowitz 1996).

Wildlife species populations in the Limpopo Valley of Mozambique were decimated during years of civil war (1974-1990). However, the establishment of the Greater Limpopo Transfrontier Park (GLTFP), linking the Kruger National Park (KNP) in South Africa, Gonorezhou National Park in Zimbabwe and the newly created Parque Nacional do Limpopo (PNL) in Mozambique, has permitted the recovery of some wildlife species populations into the area (Hanks 2000). It is interesting to note that in the 1960s the converse had occurred; where the region now designated as PNL acted as a reservoir for the recovery of over-exploited elephant populations into KNP (Whyte et al.2003).

The cheetah (Acinonyx jubatus Schreber, 1775), is a species that may benefit from transboundary conservation agreements. It occurs at naturally low population densities, makes use of large home ranges, and disperses over long distances, thus requiring large tracts of suitable habitat to maintain viable population sizes (IUCN/SSC 2007). Cheetahs are prey specialists (Hayward et al. 2006). Cheetah were thought to have been extirpated from the Limpopo Valley in Mozambique during the civil war (Purchase 2007); however, PNL was listed as possible cheetah range due to a lack of empirical data from the area and its contiguousness with KNP (IUCN/SSC 2007). Here we present the first scientific evidence of a breeding population of cheetah in PNL, Mozambique. These results highlight the importance of the GLTFP to the overall conservation of cheetah in southern Africa, and the potential value of transboundary protected areas for the conservation of wideroaming terrestrial mammals.

\section{METHODS}

Data were obtained from camera-traps deployed during occupancy surveys conducted from $9 \mathrm{Sep}$ tember 2011 to 31 August 2012 over a $3400 \mathrm{~km}^{2}$ study area located within the central third of PNL (Fig. 1). A total of 81 camera stations were established over the entire study period. One Reconyx HC500 (Wisconsin, U.S.A.), Bushnell Trophy Cam (Bejing, China) TrailMaster (Kansas, U.S.A.) or DeerCam (Wisconsin, U.S.A) remote camera was placed at each camera station. Camera stations were established on existing roads, game trails and natural landscape features that facilitate cheetah 


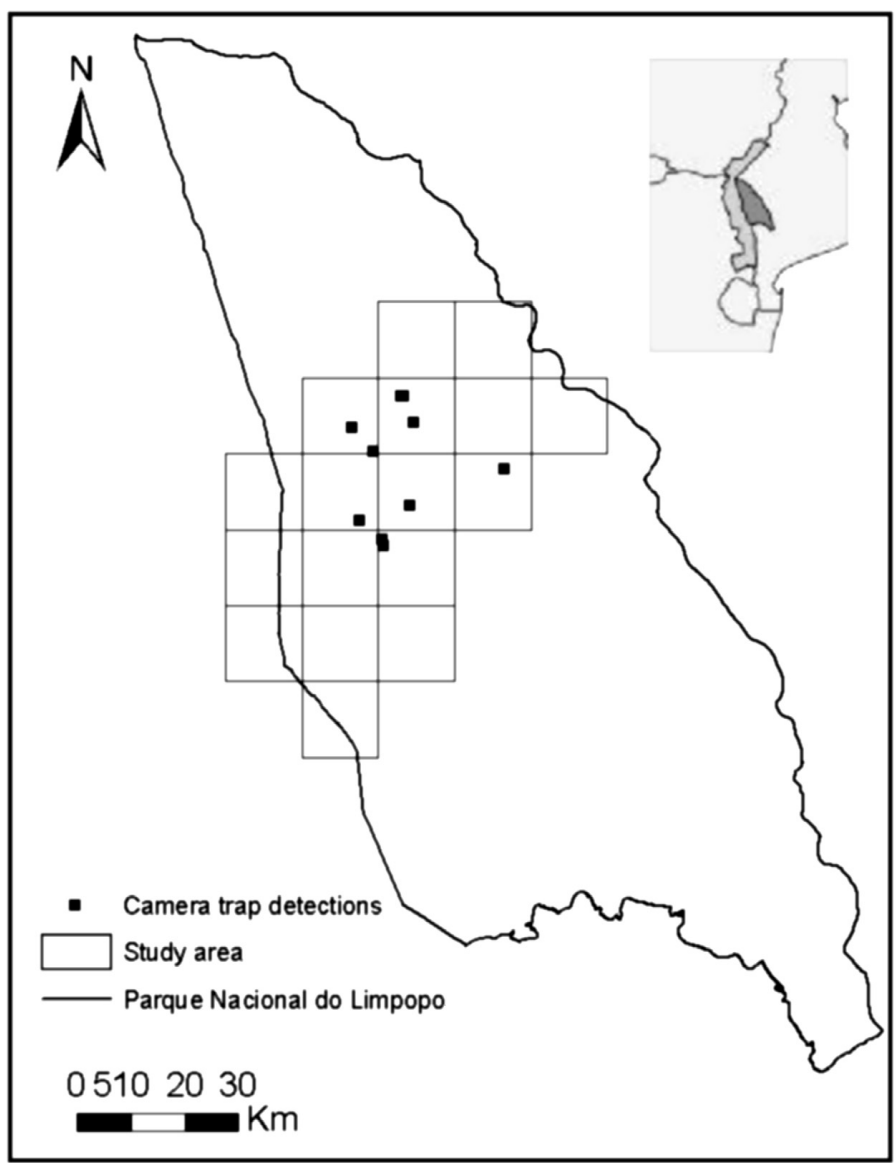

Fig. 1. Study area, location of camera traps that detected cheetah within the Parque Nacional do Limpopo (PNL), Mozambique. Inset map: location of PNL (dark grey) in Mozambique and in relation to the Greater Limpopo Transfrontier Park.

movements or increase the probability of their detection (Karanth et al. 2004), which in our study area included water holes, the peripheries of pans, dry river beds and termite mounds. Minimum counts of cheetah were determinedby using their unique spot patterning to identify individuals (Karanth 1995), from photographs obtained from camera-traps.

\section{RESULTS}

Camera traps obtained 1250 cheetah photographs, comprising 61 separate cheetah capture events over the study period. Seventeen individual cheetahs were identified in the survey area. They included one lone female, one female with two subadult cubs, one female with three subadult cubs, one female with a cub less than one year, two lone males, one coalition of two males, and one group of three animals of unknown sex. Cheetahs were photographed from 11 camera stations in the study area.

\section{DISCUSSION}

Our preliminary findings provide evidence of a resident population of cheetahs in PNL. Cheetahs were thought to have been extirpated from the Limpopo Valley in Mozambique during 16 years of civil war and unrest due to severe prey depletion and hunting for their skins (Purchase 2007). Our data provide the first scientific evidence of a breeding population in this region, with a number of different groups suggesting a viable population structure. The presence of multiple females with young of different age classes provides evidence that the population is not restricted to dispersing animals, and can be thus considered a resident population.

Whether this population is the result of recoloni- 
sation or recovery of a population that had persisted at low densities during the civil war is unknown. In either case it is likely that the establishment of the GLTFP has facilitated this recovery. Furthermore, the fact that there is a resident population of cheetah in PNL is encouraging for the potential recovery of cheetah in neighbouring protected areas in Mozambique (Banhine National Park and Zinave National Park), providing the protection of suitable corridors and the recovery of prey populations. These preliminary results form part of a longer-term study into the population ecology of cheetahs in this region of Mozambique, which will provide more detailed information regarding their status.

We thank the University of Pretoria and the Wilderness Trust for funding. Thanks goes to the Director Nacional Conservation Areas Mozambique for granting us a research permit and the park warden Baldeau Chande for allowing us access to the park. Matt Hayward provided useful comments on an earlier version of the manuscript.

\section{REFERENCES}

HANKS, J. 2000. The role of Transfrontier Conservation Areas in southern Africa in the conservation of mammalian biodiversity In: A. Entwistle \& N. Dunstone (Eds) Priorities for the conservation of mammalian diversity. Has the panda had its day? Cambridge University Press, Cambridge.

HAYWARD, M.W., HOFMEYR, M., O'BRIEN, J. \& KERLEY, G.I.H. 2006. Prey preferences of the cheetah Acinonyx jubatus: morphological limitations or the need to capture rapidly consumable prey before kleptoparasites arrive? J. Zool., Lond. 270: 615-27.

IUCN/SSC. 2007. Regional conservation strategy for the cheetah and wild dog in southern Africa. IUCN Species Survival Commission, Gland.

KARANTH, K.U. 1995. Estimating tiger Panthera tigris populations from camera-trap data using capturerecapture models. Biol. Cons. 71: 333-338.

KARANTH, K.U., NICHOLS, J.D. \& KUMAR, N.S. 2004. Photographic sampling of elusive mammals in tropical forests. In: W.L. Thompson (Ed), Sampling rare or elusive species. Island Press, Washington.

PURCHASE, G. 2007. Mozambique: preliminary assessment on the status and distribution of cheetah. CAT News Special Issue 3: 37-39.

WEBER, W. \& RABINOWITZ, A. 1996. A global perspective on large carnivore conservation. Cons. Biol. 10(4): 1046-1054.

WHYTE, I.J., VAN AARDE, R.J. \& STUART, P. 2003. Kruger's elephant population: its size and consequences for ecosystem heterogeneity. In: J.J. du Toit, K.H. Rodgers \& H.C. Biggs (Eds), The Kruger experience: ecology and management of savannah heterogeneity. Island Press, Washington.

WOODROFFE, R. \& GINSBERG, J. 1998. Edge effects and the extinction of populations inside protected areas. Science 280: 2126-2128. 